CENTRO, Vol. 1, No. 1. 1984, pp. 41-48.

(C) University of Malta Press.

\title{
Note on the Ecology of Mollusca Collected in Haifa Bay (Israel)
}

\author{
HAVA HORNUNG*, ALEXANDER BARASH ${ }^{+}$AND ZIPPORAH DANIN ${ }^{+}$ \\ *Israel Oceanographic and Limnological Research, Tel Shikmona, \\ P.O.B. 8030, Haifa, Israel. \\ ${ }^{+}$Department of Zoology, Tel-Aviv University, Ramat Aviv, Israel.
}

(Received 15th November 1983)

\begin{abstract}
Four surveys concerned with heavy metal pollution were carried out during July, November 1980 and July, September 1981 in Haifa Bay. Observations were made at a number of stations at four depths on the occurrence of various species of molluscs and their environment (type of sediment, temperature, $\mathrm{pH}$, dissolved oxygen and salinity of the water) at each site. General conclusions are drawn on the distribution of the species at these depths. Arcularia gibbosula proved to be the most abundant living species in the bay as well as a suitable indicator for mercury pollution.
\end{abstract}

\section{Introduction}

Coastal and estuarine waters are being increasingly burdened by metal pollution. Populations of benthic communities may be damaged if such pollution continues. Studies on trace metal pollution in the sea have generally utilized bivalve molluscs as indicators of metal concentrations in their environment (Eisler et al., 1972; Cunningham and Tripp, 1975; Phillips, 1977; Gordon, 1980). During our study on heavy metal pollution in Haifa Bay the gastropod, Acularia gibbosula was found to be the most suitable bioindicator for mercury pollution. (Hornung et al., 1984).

The distribution of the bottom dwelling and burrowing molluscan species and the ecology of their habitat are discussed in this paper. A study of the macrobenthos of 
Haifa Bay was carried out by Gilat (1959) and Tom (1976). These studies were made using a Petersen grab and a triangular dredge as sampling gear. The depths investigated varied from 10 to $97 \mathrm{~m}$.

Samples for the present study (sediments and fauna) found in the surface layers $(0$ $10 \mathrm{~cm}$ depth of the bottom) at water depths from 3 to $12 \mathrm{~m}$ were collected by SCUBA divers during the surveys for the study of heavy metal concentrations in sediments and benthic organisms of Haifa Bay.

\section{Sampling Area and Methods}

Haifa Bay forms a sickle-shaped curve between Akko on the north and Cape Carmel on the south. A sandy zone of about $1 \mathrm{~km}$ width follows the curve of the shore from a depth of $0-12 \mathrm{~m}$ (Nir, 1973).

The depths sampled were $3,6,9$ and $12 \mathrm{~m}$. The number of sampling stations varied with depth: 8 stations at depth of $3 \mathrm{~m}, 6$ stations at $6 \mathrm{~m}, 5$ stations at $9 \mathrm{~m}$ and 4 stations at $12 \mathrm{~m}$ (Fig. 1). Four surveys were carried out - July, November 1980 and July, September 1981 .

Sediments and benthic fauna (mostly Mollusca) were collected at each sampling site from the surface of one square meter of the sea floor to a depth of $10 \mathrm{~cm}$ (Fig. 1). The SCUBA divers collected the sediments using plastic scoops and plastic bags. Nylon

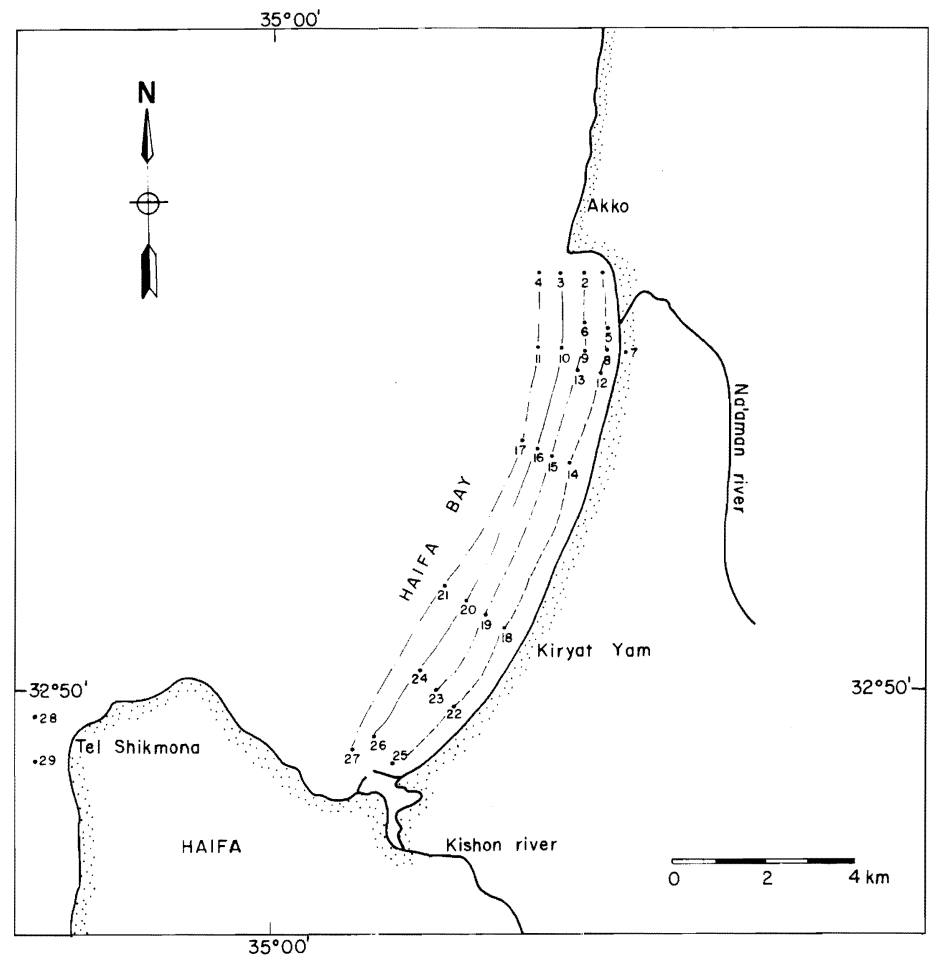

Fig. 1. Location of sampling stations. 
sieves with square holes $2.5 \mathrm{~mm}$ across were used for separating the animals-molluscs.* Only living specimens were picked out of the sieve; dead and broken shells were ignored.

Water samples were collected at each sampling site from the water-sediment interface layer using a special water sampler. The temperatures of the water layer above the sediment and the whole water column were measured by a cable-thermistor thermometer.

\section{Results and Discussion}

a. Water. The water temperature of the sediment-water interface, during the sampling periods ranged from 27.1 to $29.2^{\circ} \mathrm{C}$ in July, from 26.2 to $28.0^{\circ} \mathrm{C}$ in September and from 22.2 to $22.8^{\circ} \mathrm{C}$ in November. The $\mathrm{pH}$ of the water was the same during the four surveys and ranged from 8.02 to 8.30 . The salinity was the same for the whole shoreline during these months for these depths (Oren and Hornung, 1972) ranging from 39.084 to $39.329 \%$. The dissolved oxygen in the water samples collected from the water layer above the sediment ranged from 3.17 to $5.54 \mathrm{ml} / 1$ with one low value of $2.23 \mathrm{ml} / 1$ at $12 \mathrm{~m}$ depth.

b. Sediments. The sediments from the shoreline up to $9 \mathrm{~m}$ depth are composed mostly of fine sand $(250-125 \mu \mathrm{m}$ fraction) with small quantities of very fine sand (125$63 \mu \mathrm{m})$ and silt $(<0.063 \mu \mathrm{m}$ fraction). It can be seen from the granulometric analysis given in Table 1 that the percentage of fine sand grains decreased with distance from shore. From the $12 \mathrm{~m}$ depth line the sea floor is composed of submarine reefs and ridges with pockets of very coarse calcareous sand and gravels, and sampling of organisms was almost impossible.

The range for organic carbon in the sediment samples found previously by Roth and Hornung (1975) at the same area was $0.02-0.32 \%$. These values are similar to those given by Nir (1973) for the Israel Mediterranean shelf.

c. Mollusca. A total of 18 species were found (Table 2) during the four surveys. Subspecies of 2 species (Hinia reticulata and Mactra corallina) were also recorded.

Over 700 species of mollusca have been collected in the Mediterranean waters of Israel (Barash and Danin, 1982). These were obtained from shallow water accessible to

Table 1 Grain-size distribution (expressed in weight $\%$ ) of the analyzed sediments

\begin{tabular}{|c|c|c|c|c|c|c|c|c|}
\hline \multirow{2}{*}{$\begin{array}{l}\text { Water } \\
\text { column } \\
\text { depth } \\
\text { line } \\
\text { (m) }\end{array}$} & \multirow{2}{*}{$\begin{array}{l}\text { Distance } \\
\text { from } \\
\text { shore } \\
\text { (m) }\end{array}$} & \multicolumn{7}{|c|}{ Granulometric fraction $(\mu \mathrm{m})$} \\
\hline & & $>2000$ & $\begin{array}{l}2000- \\
1000\end{array}$ & $\begin{array}{c}1000- \\
500\end{array}$ & $\begin{array}{l}500- \\
250\end{array}$ & $\begin{array}{l}250- \\
125\end{array}$ & $\begin{array}{l}125- \\
0.063\end{array}$ & $<0.063$ \\
\hline 3 & 300 & 0.79 & 0.60 & 1.68 & 6.74 & 83.68 & 6.42 & 0.07 \\
\hline 6 & 500 & 0.87 & 0.51 & 1.45 & 5.40 & 76.30 & 14.77 & 0.62 \\
\hline 9 & 700 & 2.32 & 0.70 & 2.97 & 4.86 & 67.96 & 18.49 & 2.70 \\
\hline 12 & $900-1000$ & 13.45 & 30.46 & 44.38 & 10.04 & 1.55 & 0.16 & 0 \\
\hline
\end{tabular}

* Most Rissoacea known in this area are above $2.5 \mathrm{~mm}$ in height while almost all Turridae surpass the height of $2.5 \mathrm{~mm}$ (Parenzan, 1970). 
shore collectors or taken by dredgings in the infralittoral at depths between 9-200 m. The stretch of the infralittoral between the intertidal zone and $9 \mathrm{~m}$ depth had scarcely been investigated, since the research vessels were generally unable to carry out dredgings there. This strip of the infralittoral was explored by diving in our present surveys. Prior to our work in this area, 58 species of Mollusca were collected in the same strip of the infralittoral. These collections were, however, only occasionally carried out by private divers over a period of 18 years (1959-1977).

The composition of the 18 species mentioned in this paper is restricted to the major taxa of Mollusca: Gastropoda - 9 species and Bivalvia - 9 species. It is worth noting that the Bivalvia are represented equally with the Gastropods, despite the preponderance of the latter among the Mollusca in general. (The number of recorded Gastropoda species of the Israeli Mediterranean coast amounts to 474 and that of Bivalvia to 192.)

The most abundant species among those found during the surveys (Table 2, Fig. 2) is Arcularia gibbosula, represented by 199 specimens, circa $39 \%$ of the 517 specimens in toto. (Tom 1976) found only a few specimens of Arcularia gibbosula at Haifa Bay. Barash and Danin (1982) indicated merely as common the frequency of this species in the Mediterranean waters of Israel.)

A great number of specimens was collected during the relatively colder months of the year: November 1980 - 195 specimens, September 1981 - 187 specimens, whereas in

Table 2 List of recorded molluscan species

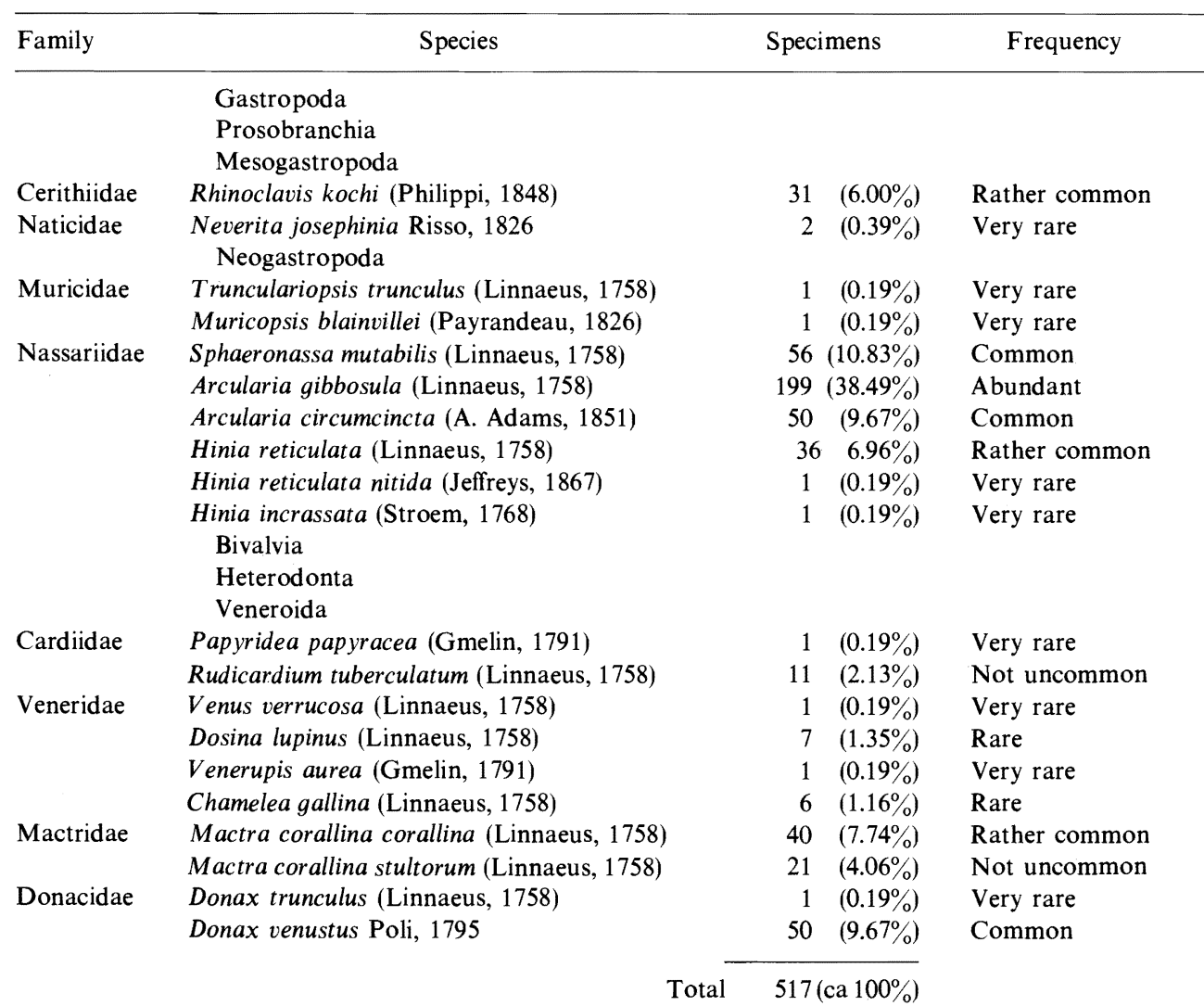




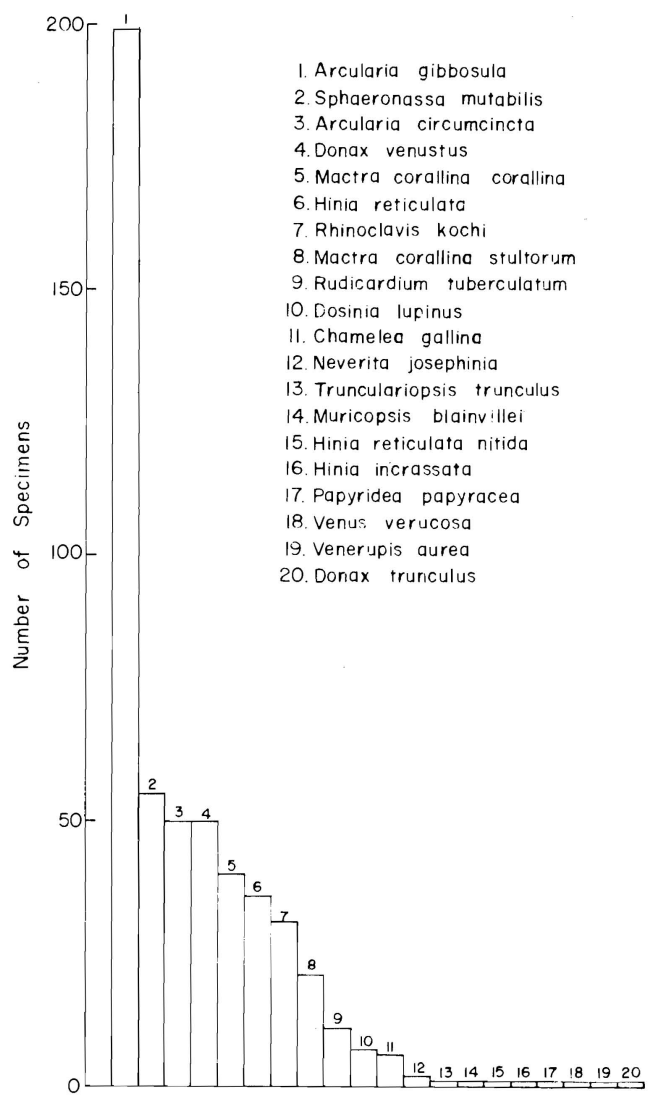

Fig. 2. Occurrence of species.

the warmer season a considerably smaller number of specimens was taken; namely, in July 1980 - 33 specimens, July $1981-102$ specimens.

It can be surmised that specimens of species hidden under the surface during the warm period appear on the surface when the temperature falls. Tom (1976) found seasonal changes in the composition of species burrowing in the sediments. Certain species appear on the surface of the bottom in the warm months of the year and under the surface in other seasons.

Most species were taken from depths of 3-9 m, from more or less soft bottoms (sand, sandy mud). A smaller number of species (8) was obtained from a depth of $12 \mathrm{~m}$, where the substrate is rather hard (Table 3 ). Between the 3 and $6 \mathrm{~m}$ depth lines 341 specimens were collected (about 24 specimens for each $\mathrm{m}^{2}$ ) and between the 9 and $12 \mathrm{~m}$ depth lines only 176 specimens were obtained (about 20 specimens for each $\mathrm{m}^{2}$ ).

All the species dealt with in this paper are able to burrow in the bottom. Typically infaunal animals are the Bivalvia and the naticid Neverita josephinia, which live permanently within the bottom.

The Nassariidae dwell under the surface but are also able to move on the bottom. Trunculariopsis trunculus and Rhinoclavis kochi are more frequent on and above the sediments. T. trunculus burrows shallowly in the sediments in the summer and is abundant above the sediment in the colder months of the year (Spanier, 1981). 
Table 3. Vertical and seasonal distribution of species collected by diving in Haifa Bay during 1980-1981 (No. of specimens indicated)

\begin{tabular}{|c|c|c|c|c|c|c|c|c|c|c|c|c|c|c|c|c|c|}
\hline \multirow{3}{*}{ Species } & \multicolumn{4}{|c|}{$3 \mathrm{~m}$} & \multicolumn{4}{|c|}{$6 \mathrm{~m}$} & \multicolumn{4}{|c|}{$9 \mathrm{~m}$} & \multicolumn{4}{|c|}{$12 \mathrm{~m}$} & \multirow{3}{*}{ Total } \\
\hline & \multicolumn{2}{|c|}{1980} & \multicolumn{2}{|c|}{1981} & \multicolumn{2}{|c|}{1980} & \multicolumn{2}{|c|}{1981} & \multicolumn{2}{|c|}{1980} & \multicolumn{2}{|c|}{1981} & \multicolumn{2}{|c|}{1980} & \multicolumn{2}{|c|}{1981} & \\
\hline & Jul & Nov & Jul & Sep & Jul & Nov & Jul & Sep & Jul & Nov & Jul & Sep & Jul & Nov & Jul & Sep & \\
\hline Rhinoclavis kochi & - & $\ldots$ & - & - & - & 10 & - & - & - & 6 & - & 10 & - & 5 & - & - & 31 \\
\hline Neverita josephinia & - & - & - & 1 & - & - & - & 1 & - & - & - & - & - & - & - & - & 2 \\
\hline Trunculariopsis trunculus & - & - & - & - & - & - & - & - & - & 1 & 一 & - & - & - & - & - & 1 \\
\hline Muricopsis blainvillei & - & - & - & - & - & - & - & - & - & - & - & & 1 & - & - & - & 1 \\
\hline Sphaeronassa mutabilis & 1 & - & 1 & 6 & - & 1 & - & 1 & 1 & 13 & 2 & 6 & - & 17 & - & 7 & 56 \\
\hline Arcularia gibbosula & 1 & 22 & 19 & 28 & - & 54 & 13 & 29 & - & 4 & 8 & 22 & - & - & - & - & 199 \\
\hline Arcularia circumcincta & 8 & 8 & 6 & 12 & 6 & - & - & 2 & 8 & - & - & - & - & - & - & - & 50 \\
\hline Hinia reticulata & - & 1 & - & - & - & - & - & - & - & 7 & - & 1 & - & 26 & - & 1 & 36 \\
\hline Hinia reticulata nitida & - & - & - & - & - & - & - & - & - & 1 & - & - & - & - & - & - & 1 \\
\hline Hinia incrassata & - & 1 & - & - & - & - & - & - & - & - & - & - & - & - & - & - & 1 \\
\hline Papyridea papyracea & - & - & - & - & - & - & - & - & - & - & - & - & - & - & - & 1 & 1 \\
\hline Rudicardium tuberculatum & - & - & - & - & - & 1 & 1 & 2 & - & 2 & 1 & 2 & - & - & - & 2 & 11 \\
\hline Venus verrucosa & - & - & - & 一 & - & - & - & - & - & - & - & - & - & - & 1 & - & 1 \\
\hline Dosinia lupinus & 3 & - & - & - & - & - & - & - & - & - & - & - & - & - & - & 4 & 7 \\
\hline Venerupis aurea & - & - & - & - & - & - & - & - & - & - & 1 & - & - & - & - & - & 1 \\
\hline Chamelea gallina & - & - & - & - & - & 1 & 1 & - & - & 2 & - & - & - & - & - & 2 & 6 \\
\hline Mactra corallina corallina & 2 & 1 & 8 & 10 & 1 & 1 & 4 & 10 & - & - & 1 & 2 & - & - & - & - & 40 \\
\hline Mactra corallina stultorum & 5 & - & - & 10 & - & - & 2 & 2 & - & - & 1 & 1 & - & - & - & - & 21 \\
\hline Donax trunculus & 1 & - & - & - & - & - & - & - & - & - & - & - & - & - & - & - & 1 \\
\hline Donax venustus & - & 6 & 21 & 6 & 1 & - & 5 & 5 & - & 4 & - & 1 & - & - & 1 & - & 50 \\
\hline Specimens total & 20 & 39 & 55 & 73 & 8 & 68 & 26 & 52 & 9 & 40 & 14 & 45 & 1 & 48 & 2 & 17 & 517 \\
\hline
\end{tabular}


Rhinoclavis kochi seems also to be a shallow burrower. The egg masses of this species are covered by sand grains adhering to the gelatinous matrix in which the egg capsules are embedded.

The modes of feeding of the species collected are diverse. Archaeogastropoda were not found during the surveys and hence no typical herbivorous species feeding on macrophyte algae were available. Of the 2 species of Mesogastropoda, Rhinoclavis kochi feeds on minute algae and detritus; the other species, Neverita josephinia, preys on molluscs, boring holes through their shells and then rasping out the living contents. The other Gastropoda ( 8 species), belonging to the Neogastropoda, are carnivorous. Of these, the five species of Nassariidae are in the main scavengers, feeding mainly on dead animal matter. The nassariids are of great importance for the ecology of the waters, keeping them clean by disposing of all kinds of decaying organisms.

Our investigations concerning the pollution of Haifa Bay proved that the most efficient species in the uptake of mercury are the nassariids Arcularia gibbosula and Arcularia circumcincta (Hornung et al., 1984). (Arcularia circumcincta is regarded by some authors as a synonym of $A$. gibbosula and by others as a variety.)

The effect of industrial contamination is demonstrated by a comparison of mercury content in bivalve and gastropod species from distant and close sampling sites, where emission of waste water containing mercury takes place (Fig. 3). The decrease of mercury content in the soft tissues of the molluscs with the increasing distance from the pollution source can be seen very distinctly.

Based upon these findings it is clear that Arcularia gibbosula, which is the most
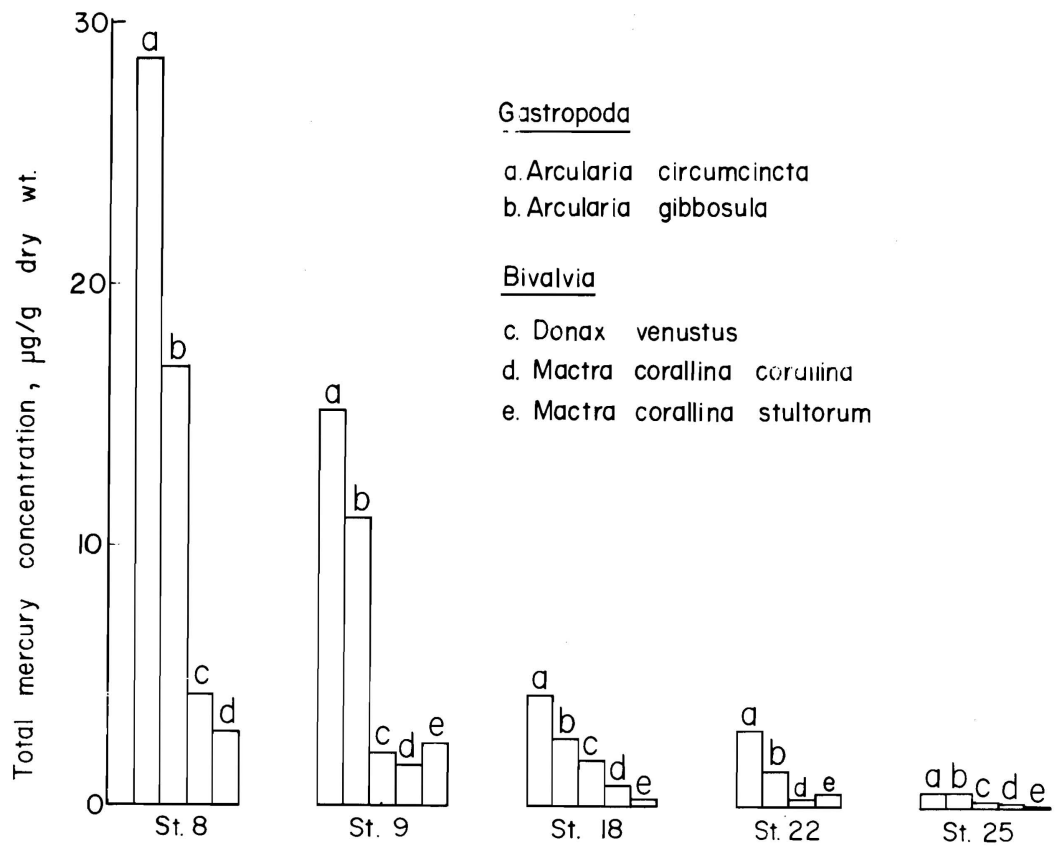

Fig. 3. Total mercury concentrations in molluscs (bivalves and gastropods) along sampling sites in Haifa Bay, 1980-1981 Hornung 1984). 
abundant in the area, has possibilities of being useful as an indicator species for mercury pollution.

The Bivalvia collected, belonging to the Heterodonta, are ciliary filter feeders browsing on microscopic plants and animals suspended in the water, brought to them by a water current created by cilia in their body. The accumulation of mercury in their body is much lower than in the gastropods (Fig. 3).

The results of the survey recorded here are valid only for the period studied at Haifa Bay. An extension of the surveys to other seasons of the year and to additional sites and depths, but in the same strip of the infralittoral, would probably reveal additional data on the composition of species, their frequency and seasonal changes in their assemblages.

\section{ACKNOWLEDGEMENTS}

We thank the diving staff of the Marine Physics Department (G. Brokman, M. Udell and R. Sela) and the Marine Geology Department (Ya. Ioselivskii, G. Amit and E. Adler) of Israel Oceanographic \& Limnological Research for collecting the samples and associated expertise. The criticism of Mrs. L. Zismann is greatly appreciated.

This work was supported by the Ministry of the Interior, Israel Environmental Service, Jerusalem.

\section{REFERENCES}

Barash, A. and Danin, Z. (1982) Annotated list of the Mediterranean Mollusca of Israel and Sinai. Preprint, Tel-Aviv University, The George S. Wise Center for Life Sciences, Dept of Zoology, Museum of Life Sciences, 568 pp.

Cunningham, P. A. and Tripp, M. R. (1975). Factors affecting the accumulation and removal of mercury from tissues of the American oyster Crassostrea virginica. Mar. Biol. 31:311-319.

Eisler, R. G., Zaroogian, G. E. and Hennekey, R. J. (1972). Cadmium uptake by marine organisms. J. Fish. Res. Bd. Can. 29:1367-1369.

Gilat (Gottlieb), E. (1959). Study of the benthos in Haifa Bay. Ph.D. Thesis, Hebrew University, Jerusalem, $133 \mathrm{pp}$.

Gordon, M., Knauer, G. A. and Martin, J. H. (1980). Mytilus californianus as a bioindicator of trace metal pollution: variability and statistical considerations. Mar. Pollut. Bull. 11:195198.

Hornung, H., Krumgalz, B. S. and Cohen, Y. (1984). Mercury pollution in sediments, benthic organisms and inshore fishes of Haifa Bay, Israel. Marine Environmental Research 12.

Nir, Y. (1973). Geological history of the recent and subrecent sediments of the Israel Mediterranean shelf and slope. Ph.D. Thesis, Hebrew University, Jerusalem, 179 pp.

Oren, O. H. and Hornung, H. (1972). Temperatures and salinities of the Israel Mediterranean coast. Bull. Sea Fish. Res. Stn, Haifa, 59:17-31.

Parenzan, P. (1970). Carta d'identita delle conchiglie del Mediterraneo. 1 Gasteropodi, Taranto: Ed. Bios. Taras, 283 pp.

Phillips, D. J. H. (1977). The use of biological indicator organisms to monitor trace metal pollution in marine and estuarine environments - a review. Environ. Pollut. 13:281-317.

Roth, I. and Hornung, H. (1975). Heavy metal concentrations in water, sediments and fish from the Mediterranean coastal area, Israel. Final Report. Haifa. Israel Oceanogr. Limnol. Res.

Spanier, E. (1981). Behavioral ecology of the marine snail Trunculariopsis (Murex) trunculus. Balaban ISS, Philadelphia, PA.:65-70. 